\title{
TRADING IN INFLUENCE DALAM PERSPEKTIF FIKIH KORUPSI
}

\author{
Mohammad Farid Fad \\ Dosen Fakultas Ilmu Tarbiyah dan Keguruan (FITK) \\ UIN Walisongo Semarang \\ Email:mohammadfarid@walisongo.ac.id
}

\begin{abstract}
Corruption is a deep-rooted phenomenon existing in inumerable forms that occurs in almost all countries. Of the inumerable forms of corruption, trading in influence (TI) is considered soft corruption as it is not directly inflict losses on the state. However, through misuse influence a person has, he can obtain undue advantage. This article seeks to describe critically about the practice of trading in influence from the perspective of figh corruption. The type of method used in this study was a qualitative method. Descriptiveanalitycal method was used to accurately describe and systematically analyze the facts found. This research found that fromthe perspective of Islamic criminal law, TI is considered khiyanah or ghulul (betrayal) and risywah (bribes), while the sentence is left to the policy of a judge or ruler (ta'zir), no matter whether the perpetrators are the government or private parties.
\end{abstract}

Keywords : trading in influence, undue advantage, figh corruption

\begin{abstract}
Abstrak
Korupsi merupakan fenomena yang terjadi hampir merata di berbagai negara. Dari berbagai macam varian korupsi yang ada, trading in influence (TI) termasuk kriteria korupsi yang soft, artinya, negara tidak secara langsung dirugikan, namun melalui pengaruh yang diperdagangkan, seseorang bisa memperoleh keuntungan yang tidak semestinya (undue advantage) lewat kebijakan yang bersifat memihak. Artikel ini berupaya mendeskripsikan secara kritis tentang praktek jual-beli pengaruh dalam perspektif fikih korupsi. Jenis metode yang digunakan dalam penelitian ini adalah metode kualitatif. Sementara dalam menganalisis, peneliti menggunakan metode deskriptif-analitis, guna menggambarkan serta menganalisis secara sistematis fakta yang ditemukan secara akurat dan cermat. Penelitian ini menemukan bahwa dalam perspektif hukum pidana Islam, jual-beli pengaruh dapat digolongkan dalam kategori khiyanah atau ghulul (pengkhianatan) dan risywah (suap), sementara hukumannya diserahkan pada kebijakan hakim atau penguasa (ta'zir), baik pelakunya penyelenggara negara maupun pihak swasta.
\end{abstract}

Kata Kunci : Jual Beli Pengaruh, Keuntungan Tak Semestinya, Fikih Korupsi 


\section{PENDAHULUAN}

Tanggung jawab pidana untuk kasus perdagangan pengaruh adalah fenomena yang relatif baru di berbagai belahan dunia. Pada milenium ketiga hanya sejumlah negara terbatas (Belgia, Perancis, Hongaria, Polandia, Slovenia) yang memberikan tuntutan secara eksplisit terhadap perdagangan pengaruh (Hollan, 2011: 235). Istilah trading in influence (TI) pertama kali termaktub dalam United Nations Convention Against Corruption (UNCAC) pada konvensi Perserikatan Bangsa-Bangsa (PBB). Konvensi ini telah disahkan sejak Konferensi Diplomatik di Merida, Mexico pada Desember 2003 dan bersifat terbuka agar ditandatangani oleh para peserta konvensi.

Pasal 18 konvensi tersebut berbunyi sebagai berikut:

"a. Menjanjikan, menawarkan atau memberikan kepada seorang pejabat publik atau orang lain secara langsung atau tidak langsung, suatu keuntungan yang tidak semestinya (tidak layak), agar pejabat publik itu atau orang itu menyalahgunakan pengaruhnya yang nyata, atau yang diperkirakan, dengan maksud untuk memperoleh dari (penguasa) otoritas administrasi atau publik dari Negara peserta, suatu keuntungan yang tidak semestinya bagi si penghasut (penganjur) asli tindakan tersebut atau untuk orang lain.

b. Permohonan atau penerimaan oleh seorang pejabat publik atau orang lain, secara langsung atau tidak langsung, suatu keuntungan yang tidak semestinya untuk dirinya sendiri atau untuk orang lain agar pejabat publik itu atau orang itu menyalahgunakan pengaruhnya yang nyata atau yang diperkirakan dimilkinya, dengan maksud memperoleh dari (penguasa) otoritas adminstrasi atau otoritas publik dari Negara peserta suatu keuntungan yang tidak semestinya."

Frase "manfaat atau keuntungan yang tidak semestinya" (undue advantage) dalam UNCAC tersebut memiliki interpretasi yang beragam, mulai dari keuntungan materiil yang dijanjikan kepada pejabat publik atau orang lain, hingga persoalan menempatkan pejabat publik atau pihak lain dalam posisi menerima keuntungan atas kebijakan-kebijakannya dengan menyalahi prosedur atau mekanisme administrasi yang semestinya. Umumnya, yang menjadi tujuan pokok praktek perdagangan pengaruh adalah keuntungan materiil. Sementara unsur "kesengajaan" lebih ditekankan karena pelaku menginginkan menggunakan pengaruhnya dan mengerti konsekuensinya.

Indonesia telah menandatangani konvensi tersebut dan meratifikasinya ke dalam Undang-Undang Nomor 7 Tahun 2006 tentang Pengesahan United Nations Convention Against Corruption, 2003 (Konvensi Perserikatan Bangsa-Bangsa Anti Korupsi, 2003) pada 19 September 2006. Kontrasnya, hingga saat ini Indonesia belum merevisi Undang-undang Pemberantasan Tindak Pidana Korupsi Indonesia yang selaras dengan 
UNCAC tersebut. Celah hukum inilah yang sering dimanfaatkan perorangan atau kelompok untuk melakukan perbuatan yang sebenarnya bisa dikategorikan sebagai korupsi. Misalnya, oknum petinggi partai politik ataupun keluarga yang memiliki pengaruh politik tertentu yang sengaja memanfaatkan pengaruh ataupun kedekatannya tersebut dengan pihak lain ataupun orang yang berkepentingan. Titik tekan pada faktor pengaruh itulah yang biasa mendatangkan keuntungan-keuntungan tertentu.

Secara umum, memperdagangkan pengaruh dapat didefinisikan sebagai tindakan menjanjikan dan atau memberi keuntungan yang tidak semestinya kepada pihak lain, atau setidaknya ia dapat memberikan pengaruh yang tidak patut terhadap pihak ketiga. Secara khusus perilaku ini dapat dikualifikasikan sebagai suap aktif dari pihak yang berkepentingan kepada pejabat publik dengan mengharapkan keuntungan dari pengaruhnya yang tidak semestinya. Perilaku penyuap yang meminta, menerima keuntungan yang tidak semestinya ataupun janji darinya yang biasanya disebut perilaku suap pasif. Sedangkan tindak suap dalam perdagangan pengaruh yang aktif berarti bahwa seseorang menjanjikan, memberi, atau menawarkan sesuatu yang tidak semestinya keuntungan bagi seseorang yang mengkonfirmasi bahwa ia bisa memberi pengaruh yang tidak semestinya dari pihak ketiga.

Secara sederhana, perbedaan tindak jual-beli pengaruh dengan suap adalah pihak yang meraup manfaat dalam memperdagangkan pengaruh bukan melulu policy maker, tetapi mereka yang berupaya menggunakan posisi dan daya tawarnya guna meraih keuntungan (Manohara, 2017: 62). GREGO (Group as States Againts Corruption) menyatakan:

"The difference between (trading in infuence) and bribery is that the influence peddlerisno required to "act or refrain from acting" as would a public official. The recipient ot the undue advantage assist the person providing the undue advantage by exerting or proposing to exert an improper influence over the third person who may perform (or abstain from performing) the requested act" (Manohara, 2017: 63).

Perbedaan lainnya adalah subjek hukum yang menerima suap. Dalam perdagangan pengaruh, pelaku bisa saja berasal dari bukan aparatur negara, namun memiliki kewenangan atau otoritas publik. Titik tekannya lebih kepada kekuasaan, bukan pada jabatan formalnya. Sebab tidak mustahil orang yang tidak memegang jabatan formal namun memiliki pengaruh yang luas serta daya tawar tinggi. Demikian juga bagi orang-orang yang memiliki akses serta kedekatan tertentu dengan pejabat-pejabat yang berwenang, ia bisa saja memanfaatkan kedekatannya tersebut guna mempengaruhi kebijakan pejabat agar menguntungkannya. 
Dalam prakteknya, modus operandi jual-beli pengaruh bisa melibatkan tiga pihak (trilateral relationship), dua aktor dari sisi pembuat kebijakan, dan satu pihak yang aktif memberi sesuatu untuk mendapatkan manfaat ataupun kemudahan dari pejabat publik. Ataupun bisa saja hanya melibatkan dua pihak (bilateral relationship), pemberi sesuatu menginginkan keuntungan secara langsung dari pejabat publik. Sedangkan pada suap atau gratifikasi, penerimanya harus seorang pegawai negeri atau administrator negara. Untuk itu, pelaku memperdagangkan pengaruh sebenarnya dapat dijerat dengan UndangUndang Tindak Pidana Korupsi, dengan dikorelasikan pada pasal-pasal terkait suap. Namun dalam tindak pidana suap, antara penyuap dan yang disuap itu ada sebuah relasi kontraktual dan harus bersifat resiprokal, saling bertukar manfaat. Sementara pelaku jual-beli pengaruh, yang memperdagangkan pengaruh belum tentu pihak yang memperoleh manfaat secara langsung.

Sebenarnya, tindak jual-beli pengaruh telah berulang kali terjadi, dengan modus yang bervariasi. Diantaranya seringkali saat pembuat kebijakan menggunakan wewenang politiknya sebagai alat untuk mempertahankan kekuasaan, status, kekayaannya ataupun fasilitas kemudahan lainnya. Apalagi jual-beli pengaruh seringkali dihubungkan dengan pembiayaan politik secara illegal atau dikenal dengan jenis korupsi trilateral dengan pelaku tidak hanya pejabat negara, tetapi juga warga negara biasa melalui insentif janji atau hadiah (Hamzah, 2007: 251). Permisalan sederhana kasus memperdagangkan pengaruh ialah bila ada pengusaha yang menjadi donatur politik kepala daerah, ingin merevisi besaran nominal retribusi dalam Perda Retribusi disebabkan dinilai menambah berat laju bisnisnya. Perda tersebut mengatur bahwa setiap moda transportasi yang melewati Kabupaten/Kota A harus membayar restribusi sebesar Rp. 20.000 per ton hasil tambang yang melintasi jalanan tersebut. Karena merasa hutang jasa, B tidak keberatan bila Perda tersebut diubah. Hasil revisinya menurun drastis hingga Rp. 5.000 per ton (Fariz, 2014: 30-31).

Ada pula kasus riil yang terjadi, yaitu Irman Gusman (mantan Ketua DPD) dengan jabatannya dituduh mempengaruhi kuota gula impor yang diberikan Perusahaan Umum Badan Urusan Logistik (Bulog) kepada CV Semesta Berjaya untuk Provinsi Sumatera Barat pada tahun 2006. Serta kasus kuota sapi impor yang melibatkan Lutfi Hasan Ishaq sebagai anggota DPR RI Komisi I yang mencoba mempengaruhi Menteri Pertanian Suswono lewat jabatannya.

Lewat peristiwa-peristiwa hukum tersebut, dapat diindikasikan bahwa jual-beli pengaruh bermula dari fenomena kewenangan luas yang dimiliki oleh pejabat publik yang disertai diskresi tanpa batas namun nirakuntabilitas, maka membuka kesempatan luas bagi menjamurnya 
praktek ini. Lalu, bagaimana hukum Islam memandang praktek perdagangan pengaruh ini? Artikel ini akan lebih memfokuskan diri menganalisis tentang perdagangan pengaruh dalam perspektif fikih korupsi.

\section{METODE PENELITIAN}

Jenis metode yang dipakai dalam penelitian ini adalah metode kualitatif. Hal ini disebabkan oleh apa yang dilakukan dalam penelitian ini yang tidak bertujuan untuk mengukur hubungan antar variable, akan tetapi bertujuan untuk menganalisis jual-beli pengaruh dalam perspektif fikih korupsi. Setelah data terkumpul, akan dilakukan analisis dengan menggunakan metode deskriptif-analitis, yaitu menggambarkan secara sistematis fakta yang ditemukan secara akurat dan cermat, serta dilakukan analisis secara kualitatif guna mendapatkan pemahaman terhadap problem yang diteliti secara lebih mendalam.

\section{PEMBAHASAN}

\section{Konsep Jual-Beli Pengaruh}

Islam telah mengajarkan agar dalam ikhtiar mendapatkan harta diperoleh melalui cara-cara yang beradab dan sesuai dengan ajaran AlQur'an dan Hadist. Tidak dilakukan melalui penipuan, memakan harta riba, mencuri atau mengambil hak orang lain secara bathil, curang dalam takaran, jalan korupsi, dan lain sebagainya.Para yuris telah sepakat mendefinisikan bahwa harta akibat cara-cara tersebut adalah jenis perbuatan yang diharamkan oleh al-Qur'an (Q.S. 2: 188, 3: 161, 4: 29). Rasulullah SAW juga telah mencontohkan dirinya sendiri untuk tidak mentolerir perilaku koruptif, Beliau SAW bersabda, "Demi Allah yang jiwaku ada di tangan-Nya, seandainya Fatimah putri Muhammad mencuri niscaya aku yang akan memotong tangannya" (HR Bukhari dan Muslim).

Lord Acton dalam uraian populernya menyatakan power tends to corrupt, absolute power corrupt absolutely, hal ini karena pemegang kekuasaan memiliki posisi yang superior, ia bisa memanfaatkan pengaruhnya untuk perkara-perkara yang menguntungkan dirinya sendiri ataupun orang lain. Artinya, semakin tinggi jabatan atau kedudukan seseorang maka semakin besar pula peluang untuk memanfaatkan pengaruhnya. Dengan kata lain, potensi seseorang untuk memaksakan kehendaknya kepada orang lain melalui kewenangannya semakin tinggi, walaupun bawahannya tidak menghendaki.

United States Institutes of Peace (http ://www.usip.org/ apachesolrsearch/ trading \%20 in \%20 influence) mendefinisikan Trading in Influence sebagai berikut:

"Someone who promises, offers, or gives to a public official, a foreign public official, an official of public international organization, or any other 
person directly or indirectly, an undue advantages in order that the public official foreign public official, foreign public official official of a public international organization, or the person abuse his or her real or supposed influence and with a view to obtaining from an administration or public authority an undue advantage for the original instigator of the act or for any other person".

Oxford Dictionary (http://www.oxforddictionaries.com) menguraikan jual-beli pengaruh sebagai berikut:

"Influence peddling is the use of position or political influence on someone's behalf in exchange for money or favour"

Titik utama perdagangan dalam pengaruh adalah nilai atau kadar pengaruh. Pengaruh yang dimanfaatkan bisa berupa pengaruh yang nyata (uang, barang berharga, promosi jabatan) ataupun yang dianggap ada (kenikmatan seksual, informasi, liburan). Pola pembuktian jual-beli pengaruh dapat dicermati dari relasi yang dimiliki para pihak, misalnya relasi kekerabatan, organisasi, pertemanan, partai atau yang lainnya.

Tujuan dari tindak pidana ini tak lain ialah memperoleh sebesarbesarnya kemanfaatan ekonomi. Selain itu, ada beban kultural pada diri pejabat publik agar memenuhi simbol-simbol kebutuhan sosial, aksesakses bisnis yang menggiurkan karena ia merasa telah berhutang jasa oleh pihak-pihak tertentu. Hingga tak jarang musim kampanye menjadi momentum tepat bagi pihak-pihak tertentu untuk menanam investasi jasa pada calon pejabat publik. Hutang jasa dan politik balas budi itu seringkali menjadi "beban moril" tertentu yang tak jarang menimbulkan rasa "ewuh pakewuh". Dari sinilah transaksi memperdagangkan pengaruh biasa bermula.

Perdagangan pengaruh tidak bisa dilepaskan dari politik biaya tinggi dalam mendayagunakan konstituen. Hal ini dikarenakan ditengah pragmatisme politik, serta biaya politik yang makin mahal, seolah menjadi keniscayaan bagi para calon pejabat publik untuk mencari investor-investor yang sanggup mendukung, bahkan membiayainya guna meraih kursi kekuasaan. Tak heran bila jual-beli pengaruh dikategorikan sebagai white collar crime. Lingkup perdagangan pengaruh tidak dibatasi, artinya, pelanggaran dapat dilakukan oleh siapa saja. Bahkan pejabat publik dapat menjadi pelaku perdagangan pengaruh dengan meminta atau menerima keuntungan yang tidak sewajarnya dengan menegaskan pengaruhnya pada pejabat publik atau pihak lain.

Jenis laku memperdagangkan pengaruh biasanya bertalian dengan tindakan gratifikasi, yaitu pejabat penyelenggara negara sebagai penerima insentif atau janji, mengetahui bahwa tawaran tersebut dimaksudkan agar ia melakukan sesuatu berdasarkan kewenangannya yang menyimpang dari etika jabatannya. Hal ini menunjukkan konsep jual-beli pengaruh 
tidak bisa dilepaskan dari tindakan menerima suap. Artinya, perdagangan pengaruh bersifat transaksional. Artinya, semakin besar nilai pemberian suap atau gratifikasinya maka peluang penyalahgunaan wewenang pejabat penyelenggara negara semakin besar pula. Demikian pula berlaku sebaliknya.

\section{Pola Jual-Beli Pengaruh}

Terdapat 2 (dua) pola kejahatan jual-beli pengaruh yaitu pertama, pola, merupakan pola perdagangan pengaruh atas dasar kekuasaan yang dimilikinya. Pola vertikal langsung berarti pihak yang berkepentingan (klien) langsung berhubungan dengan pejabat penyelenggara negara agar memanfaatkan pengaruhnya guna mendapatkan insentif tertentu. Skema ini kerap terjadi disebabkan transaksi kewenangan dalam partai politik atau instansi tertentu. Kedua, pola horizontal yaitu jual-beli pengaruh yang dilakukan melalui perantara orang berpengaruh (pejabat penyelenggara negara) yang merangkap calo (penghubung) untuk menggunakan pengaruh otoritasnya sebagai pejabat penyelenggara Negara (Fariz, 2014: 29). Sementara jenis pola horizontal dengan broker biasanya melibatkan orang-orang yang berada dilingkungan kekuasaan namun bukan menjadi aparatur negara, dengan memanfaatkan kedekatannya dengan pejabat publik yang memiliki pengaruh nyata terkait hal tertentu.

Koneksi antara pejabat publik dan pengaruhnya yang diperdagangkan bisa nyata atau hanya berdasarkan klaim. Oleh karena itu, dalam perdagangan pengaruh pola horizontal, pelaku biasanya meminta garansi kepada broker guna menerima keuntungan yang tidak semestinya dengan pernyataannya bahwa ia mampu untuk mempengaruhi seorang pejabat publik. Kedekatan relasional tersebut dipergunakan untuk mengendalikan proyek pemerintahan, sehingga ia mendapat manfaat secara langsung ataupun tak langsung dari proyek tersebut. Model terakhir ini banyak terjadi di lingkup partai politik yang mempunyai jejaring kepada kewenangan eksekutif (Saputra, 2017: 86).

Sebagai perbandingan, dalam The Nouveau Code Pénal 1994, Perancis telah mengatur pidana memperdagangkan pengaruh yang diklasifikasi menjadi dua bentuk, yaitu aktif dan pasif. Dikatakan aktif bila perbuatan tersebut dilakukan oleh pejabat publik. Sebaliknya disebut pasif bila pelakunya ialah pribadi atau swasta (Prasetio, 2017: 9). Hal ini dapat ditemukan dalam Pasal 432-11 (1) (2) (perdagangan pengaruh pasif oleh pejabat publik), Pasal 433-2 (1) (perdagangan pengaruh pasif oleh privat/swasta), Pasal 433-1 (2) (perdagangan pengaruh aktif oleh pejabat publik), dan Pasal 433-2 (2) (perdagangan pengaruh aktif oleh privat atau swasta). 
Sementara di Spanyol, tindak pidana sejenis ini diatur dalam Pasal 428-430 KUHP Spanyol yang terangkum dalam Bab 6 ayat ke-9 dengan judul del trafico de influencias, meliputi pidana perdagangan pengaruh baik aktif maupun pasif. Kanada dan Spanyol menyebut trading in influence dengan sebutan influence peddling, di Italy dikenal dengan illicit traffic of influence, di Amerika khususnya dalam hukum negara bagian Washington dikenal sebagai trading special influence. Sedangkan di Belgia, jual-beli pengaruh diatur dalam Pasal 247 ayat (4) KUHP Belgia, yang mengkriminalisasi pejabat publik yang menerima suap dalam menggunakan pengaruh yang timbul karena posisinya untuk mendapatkan perilaku tertentu dari otoritas publik.

\section{Perdagangan Pengaruh dalam Perspektif Fikih Korupsi}

Dalam perspektif fikih korupsi, perbuatan jual-beli pengaruh dapat dikategorikan sebagai perbuatan korupsi. Hal ini dikarenakan secara umum, korupsi diartikan sebagai suatu tindakan atau perbuatan orang dengan jabatan tertentu, yang menggunakan wewenangnya untuk kepentingan pribadi atau orang lain, yang berakibat merugikan uang negara.

Syed Hussein Alatas, mendefinisikan bahwa korupsi adalah transaksi tidak jujur yang bisa mendatangkan kerugian waktu, orang, dan tenaga dari pihak lain, meliputi pemerasan (extortion), penyuapan (bribery), dan nepotisme (Alatas, 1975.: 12). Adapun menurut UndangUndang Republik Indonesia Nomor 31 Tahun 1999 tentang Pemberantasan Tindak Pidana Korupsi, yang dimaksud korupsi adalah

"Setiap orang yang dikategorikan melawan hukum, melakukan perbuatan memperkaya diri sendiri, menguntungkan diri sendiri atau orang lain atau suatu korporasi, menyalahgunakan kewenangan maupun kesempatan atau sarana yang ada padanya karena jabatan atau kedudukan yang dapat merugikan keuangan negara atau perekonomian Negara".

Sementara itu, karakteristik korupsi menurut Syed Hussein Alatas yaitu (Alatas, 1975.: 12):

1) Tindak pidana korupsi biasanya melibatkan lebih dari satu pelaku. Hal ini tentu saja tidak sama dengan kasus pidana lainnya seperti kasus penipuan atau pencurian;

2) Pada umumnya korupsi diperbuat secara rahasia;

3) Kejahatan korupsi umunya melibatkan unsur kewajiban dan adanya keuntungan timbal balik;

4) Pihak yang terlibat dalam kejahatan korupsi selalu berupaya menutupi perbuatannya dengan berlindung dibalik pembenaran hukum;

5) Pihak yang terlibat korupsi berkeinginan mempengaruhi keputusankeputusan yang sifatnya menguntungkan dirinya; 
6) Setiap perbuatan korupsi mengandung unsur penipuan, lazimnya diperbuat oleh badan publik atau masyarakat;

7) Tiap bentuk korupsi adalah tindakan penghianatan atas kepercayaan;

8) Segala bentuk korupsi melibatkan fungsi ganda yang kontradiktif dari pihak-pihak yang melakukan tindakan itu;

9) Segala perbuatan korupsi melanggar norma-norma kinerja dan pertanggungjawabannya dalam tatanan masyarakat.

Dari beberapa pengertian di atas dapat disimpulkan bahwa tiap perbuatan yang beorientasi menguntungkan diri atau orang lain atau korporasi, menyalahgunakan kesempatan atau sarana, kewenangan yang ada padanya sebab kedudukan atau jabatan yang bisa berakibat merugikan perekonomian negara dapat digolongkan kejahatan tindak pidana korupsi.

Menurut Maria Silvya, jual-beli pengaruh dapat dikategorikan sebagai korupsi politik (Silvya, 2019: 42), yaitu kegiatan manipulasi lembaga politik dan aturan prosedur sehingga mempengaruhi lembaga pemerintahan dan sistem politik serta mengarah pada pembusukan kelembagaan (Amundsen, 1997: 4). Praktek perdagangan pengaruh mengindikasikan adanya tindakan penyalahgunaan kewenangan, mandat dan amanat yang dipercayakan rakyat selaku pemegang kekuasaan tertinggi dalam negara demokrasi. Selain itu, menurut Jeremy Pope, korupsi juga bisa diartikan sebagai perbuatan menyalahgunakan kepercayaan publik demi keuntungan pribadi (Pope, 2003: 6). Dengan demikian, terlihat bahwa unsur-unsur dalam jual-beli pengaruh telah memenuhi syarat disebut sebagai bagian dari tindakan korupsi.

Relasi antara sifat perdagangan pengaruh dengan tindak pidana korupsi bersifat saling interdependensi. Dengan kata lain, jual-beli pengaruh menjadi pendorong utama yang dapat menyebabkan terjadinya tindak pidana korupsi disebabkan fokus utama dari praktek perdagangan pengaruh adalah nilai pengaruh yang diperdagangkan baik melalui suap ataupun imbalan berupa gratifikasi.

Relasi kuat antara tindak pidana korupsi dengan perdagangan pengaruh ialah penyalahgunaan wewenang penyelenggara negara. Dimana penyelenggara negara mentransaksikan nilai-nilai kekuasaan, jabatan maupun pengaruhnya dengan rabat (diskon), uang, komisi, barang, pinjaman tanpa bunga, perjalanan wisata, pengobatan gratis, ataupun kemudahan fasilitas lainnya secara illegal. Hingga ia dapat memperluas jaringan ataupun meningkatkan status sosialnya dengan jejaring kekuasaan yang lebih tinggi atau dengan pejabat yang lebih besar darinya. Bahkan justru dari trading in influence inilah yang menjadi muara terjadinya persekongkolan korupsi yang lebih besar. Jual-beli pengaruh, setidaknya memenuhi unsur-unsur sebagai berikut (Fariz, 2014, 46-48):

1) Subyek hukumnya mencakup korporasi dan perorangan; 
2) Memberikan atau menerima penawaran janji atau penawaran apapun kepada pejabat publik atau orang lain;

3) Menggunakan pengaruhnya yang nyata atau yang dianggap ada;

4) Keuntungan yang tidak semestinya (the undue advantage);

5) Unsur kesengajaan;

6) Memperoleh sesuatu dari otoritas administrasi atau publik.

Delik perdagangan pengaruh tentu bertentangan dengan prinsipprinsip pokok ajaran Islam, yaitu amanah (trustable), tanggungjawab (responsibility) dan keadilan (justice for all). Perbuatan memperdagangkan pengaruh setidaknya memuat tiga pilar utama, yaitu, pertama, tasharruf, yang bermakna menerima, memberi, dan mengambil sesuatu, dengan tujuan untuk memperkaya diri sendiri, orang lain atau kelompoknya. Kedua, pengkhianatan terhadap amanat kekuasaan. Ketiga, ada kerugian yang harus ditanggung, baik oleh seseorang sebagai individu, masyarakat dan/atau Negara (Tim Penulis Muhammadiyah dan Nahdlatul Ulama, 2010: 128).

Praktek perdagangan pengaruh dalam perspektif hukum pidana Islam dapat digolongkan dalam kategori risywah (suap) dan khiyanah atau ghulul (pengkhianatan). Risywah bisa terjadi dari dua arah, baik dari rakyat kepada penguasa untuk mendapatkan kebijakan yang menguntungkan dirinya atau kelompoknya, maupun dari penguasa kepada rakyatnya dengan tujuan untuk mempertahankan dan memperluas jejaring kekuasaannya.

Suap bisa terjadi apabila unsur-unsurnya telah terpenuhi. Unsurunsur suap meliputi, pertama yang disuap (al-murtasyi), kedua, penyuap (alrasyi), dan ketiga, suap (al-risywah). Selain sebagaimana termaktub di AlQur'an (Q.S. 2: 188, 4: 29), baik yang menyuap maupun yang disuap duaduanya dilaknat oleh Rasulullah SAW, sebagai bentuk ketidaksukaannya terhadap perbuatan keduanya (al-Tamimi, 1993: 457). Bahkan saat Fath Makkah, Rasulullah SAW pernah dimintai syafaat oleh Usamah sebagai delegasi dari kaum yang meminta keringanan hukuman bagi seorang pencuri wanita. Rasulullah SAW menolaknya seraya berkhutbah sebagai berikut:

"Wahai manusia, sesungguhnya yang membinasakan orang-orang sebelum kalian adalah jika ada orang yang mulia (memiliki kedudukan) di antara mereka yang mencuri, maka mereka biarkan (tidak dihukum), namun jika yang mencuri adalah orang yang lemah (rakyat biasa), maka mereka menegakkan hukum atas orang tersebut. Demi Allah, sungguh jika Fatimah binti Muhammad mencuri, aku sendiri yang akan memotong tangannya" (Al-Bukhari, 1992: 64-65).

Dari Hadist ini terlihat bahwa Rasul SAW sendiri tidak berkenan dibujuk untuk meringankan hukuman bagi pelaku tindak pidana atas dasar pengaruh dan kewenangannya. Umar bin 'Abd al-'Aziz suatu 
ketika menolak diberi hadiah oleh seseorang karena waktu itu dia sedang menjabat sebagai khalifah. Orang yang memberi hadiah kemudian berkata, "Rasulullah pernah menerima hadiah". Lalu ia menjawab, "Hal itu bagi Rasulullah merupakan hadiah tapi bagi kita itu adalah risywah (suap) (alQardawi, 1994: 230).

Di sisi lain, praktek perdagangan pengaruh juga erat kaitannya dengan ghulul. Ghulul merupakan penyalahgunaan wewenang atau jabatan. Jabatan publik bernilai amanah, oleh karena itu, penyalahgunaan amanah dikategorikan terlarang dan hukumnya haram. Perbuatan ghulul dapat ditamsilkan sebagai tindakan menerima insentif, hadiah, atau apapun namanya yang tidak semestinya dia terima. Hal demikian sebagaimana diterangkan dalam hadits yang diriwayatkan Abu Dawud yang menyatakan bahwa pelaku ghulul itu dikenakan hukuman berupa dibakarnya harta ghulul, dan pelakunya dipukul (Al-Syaukani, tt.: 278).

Konsep ghulul dalam hukum Islam bermakna pengkhianatan atas amanah yang seharusnya dijaga. Hal ini sesuai dengan makna firman Allah Q.S. Ali Imran (3): 161. Ayat ini turun, sebagaimana diriwayatkan Ibnu Abbas, bahwa para sahabat sempat kehilangan qatifah (permadani) dalam inventaris ghanimah (rampasan) perang Badar, lalu ada sahabat yang berkata, mungkin Rasulullah telah mengambilnya, maka turunlah ayat ini yang menegaskan sangggahan terhadap mereka bahwa "tidak mungkin seorang Nabi berkhianat dalam urusan harta rampasan perang" (Katsir, 1991: 517). Adapun titik temu antara jual-beli pengaruh dengan ghulul adalah keduanya sama-sama terjadi karena penyalahgunaan wewenang serta terklasifikasi perbuatan melawan hukum dan mendekonstruksi norma serta sistem hukum masyarakat. Ghulul bisa dikatakan sebagai suatu bentuk penghianatan atas amanah jabatan yang telah diemban. Jadi semua insentif, hadiah ataupun gratifikasi yang diterima oleh seorang pejabat publik dalam rangka menjalankan tugasnya bukanlah menjadi haknya.

Rasulullah SAW telah memperluas makna ghulul menjadi dua hal, yaitu, pertama, fee atau insentif, yaitu tindakan memperoleh honor yang tidak semestinya, diluar gaji yang telah ditentukan. Rasulullah SAW bersabda, "barang siapa yang kami angkat menjadi pegawai pada suatu pekerjaan kemudian kami tetapkan gaji tertentu untuknya, maka apa yang dipungutnya sesudah itu adalah kecurangan (korupsi)" (HR.Abu Daud). Kedua, gratifikasi, yaitu pemberian yang didapatkan seorang pejabat sebab jabatan yang melekat pada dirinya. Rasulullah SAW bersabda, "hadiah yang diterima para pejabat adalah korupsi (ghulul)" (HR. Ahmad) (Baidlawi, 2009: 4).

Pada tataran ghulul dan risywah, kedua tindakan inimendapatkan sanksi ta'zir. Untuk itu, jenis hukuman ta'zir yang dapat dikenakan bagi pelaku perdagangan pengaruh yaitu: 
Tabel 1

Jenis Hukuman Bagi Pelaku Memperdagangkan Pengaruh menurut Fiqih Korupsi

\begin{tabular}{|c|c|c|}
\hline No. & Jenis Hukuman & Dalil/Dasar Hukum \\
\hline \multirow[t]{2}{*}{1.} & \multirow[t]{2}{*}{$\begin{array}{l}\text { Denda dua kali lipat dari harta yang } \\
\text { dikorupsi beserta hukuman fisik }\end{array}$} & $\begin{array}{l}\text { HR. Al-Nasa'i, Kitab } \\
\text { Sariq, No. } 4872\end{array}$ \\
\hline & & $\begin{array}{r}\text { من استعماناه علي عمل فرزقناه رزقا فهو غلول } \\
\text { (Al-Sijistan, tt.: 59) }\end{array}$ \\
\hline 2. & Pengasingan & Q.S al-Maidah (5) ayat 33 \\
\hline 3. & $\begin{array}{l}\text { Pemecatan dari jabatan (al-'azl min } \\
\text { al-wadhifah) }\end{array}$ & Q.S. Al-Anfal (8): 27 \\
\hline \multirow[t]{3}{*}{4.} & \multirow[t]{3}{*}{ Hukuman penjara } & Q.S. Ali Imran (3): 161 \\
\hline & & من استعماناه علي عمل فرزقناه رزقا فهو غلول \\
\hline & & الضرر يزال \\
\hline 5. & Hukuman mati & Q.S al-Maidah (5) ayat 33 \\
\hline 6. & $\begin{array}{l}\text { Pencabutan hak politik sebagai } \\
\text { hukuman tambahan }\end{array}$ & $\begin{array}{r}\text { Q.S. Ali Imran (3): } 161 \\
\text { الضررلا يزال بالضرر }\end{array}$ \\
\hline
\end{tabular}

Dari tabel 1 tersebut dapat dijelaskan sebagai berikut:

1) Denda dua kali lipat dari harta yang dikorupsi beserta hukuman fisik. Rasulullah SAW pernah bersabda; "Siapa saja yang mengambil barang orang lain, maka dia harus mengganti dua kali lipat dari nilai barang yang telah dia ambil dan dia harus diberi hukuman". Dalam riwayat Abu Dawud disebutkan bahwa, "Barang siapa yang kami angkat sebagai pegawai untuk suatu tugas pekerjaan, kemudian kami berikan kepadanya gaji, maka segala yang dia ambil di luar itu merupakan gulul".

2) Pengasingan (an-nafyu); hukuman ini dapat dimaknai luas, tidak saja menempatkan terpidana di suatu tempat terpencil yang jauh dari keramaian, tetapi juga bisa berupa menjauhkan terpidana dari pergaulan sosial, seperti pengucilan (An-Nawawi, tt.: 17-26).

3) Pemecatan dari jabatan (al-'azl min al-wadhifah); Jabatan yang diemban oleh seseorang merupakan amanah dari rakyat. Maka tatkala didapatkan seorang pejabat yang mengkhianati amanah publik tersebut, sudah sepatutnya diganti dengan orang lain yang lebih profesional, jujur dan memiliki integritas tinggi. Hal ini sesuai firman Allah dalam Q.S. Al-Anfal (8): 27.

4) Hukuman penjara; hukuman ini sebagai salah satu upaya represif sekaligus penjeraan terhadap terpidana pelaku jual-beli pengaruh sebagai upaya pengekangan atas kemerdekaan dan kebebasannya. 
5) Hukuman mati; dalam kondisi tertentu jika mashlahat benar- benar menghendaki, dimungkinkan koruptor untuk dihukum mati. Dalam hal ini bila pelaku melakukan tindakan penyalahgunaan wewenang secara berulang dan bahkan sampai mengancam perekonomian negara dan merongrong kedaulatan ekonomi negara.

6) Pencabutan hak politik sebagai hukuman tambahan. Penetapan bentuk hukuman bagi pelaku tindak pidana memperdagangkan pengaruh harus dipertimbangkan prinsip penegakan keadilan dan kemaslahatan umat.

Menurut peneliti, dalam memperdagangkan pengaruh, penjatuhan hukuman terhadap pelakunya diserahkan sepenuhnya kepada penguasa atau hakim setempat. Hal ini sesuai dengan konsep ta'zir dalam nomenklatur hukum pidana Islam. Disebabkan ta'zir bukanlah sejenis peraturan yang telah ditentukan kadarnya secara pasti oleh Al-Qur'an dan Hadist. Tentunya kebijakan penguasa haruslah berorientasi pada kemaslahatan publik.

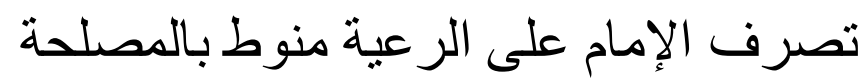

Artinya: "Kebijakan penguasa pada rakyatnya harus berorientasi maslahat".

Walaupun harus diakui, bahwa tindak jual-beli pengaruh amatlah sulit dibuktikan, karena hubungan sebab akibat antara aktor yang bertindak dan aktor yang dipengaruhi tidak begitu jelas dan tetap sulit untuk diselidiki dan dibuktikan di muka pengadilan. Disamping itu, kesulitan lainnya adalah membuktikan niat atau motif para aktor yang diduga terlibat untuk mempengaruhi seseorang atau menjadi terpengaruh dalam membuat sebuah kebijakan publik, sehingga mengarah pada tindakan penyalahgunaan pengaruh. Oleh karena itu, berdasar kasuskasus yang ada, para penegak hukum sering menimpakan pasal suap untuk perdagangan pengaruh.

Untuk itu, sebagai langkah preventif, tradisi melobi dengan memberi imbalan ataupun gratifikasi kepada pejabat, maupun melalui pengaruh dari orang lain yang berpengaruh sudah sepatutnya dihindari. Sementara dalam upaya represif, diperlukan tindakan penyadapan percakapan baik via telepon, whatsapp, line, dan aplikasi pengirim pesan lainnya. Tak cukup itu, dibutuhkan pengaturan upaya pembuktian terbalik kepada tersangka agar ia membuktikan bahwa penerimaannya tersebut merupakan penerimaan yang halal yang tidak bersangkut-paut dengan pengaruhnya. 


\section{SIMPULAN}

Perilaku memperdagangkan pengaruh bisa dikategorikan sebagai tindak pidana korupsi, sebab tujuannya adalah untuk mendapatkan keuntungan yang tidak semestinya (undue advantage) lewat penyalahgunaan pengaruhnya, baik yang diperoleh lewat jabatan formal atau lainnya. Jenis kejahatan kerah putih (white collar crime) ini tergolong telah dijalankan secara sistematis, struktural, dan senyap. Hal ini tidak terlepas dari praktek politik berbiaya tinggi (high cost politics) hingga menciptakan peluang bagi para penanam jasa untuk berinvestasi bagi para calon pejabat publik. Hutang jasa yang berujung politik balas budi itu seringkali menjadi "beban moril" tertentu bagipara pejabat publik hingga menimbulkan rasa ewuh-pakewuh. Dari sinilah biasanya praktek memperdagangkan pengaruh bermula. Perdagangan pengaruh bisa dilakukan oleh penyelenggara negara ataupun pihak swasta. Ia dapat berbentuk bilateral relationship ataupun trilateral relationship. Secara umum terdapat dua pola dalam jual-beli pengaruh, yaitu vertikal dan horizontal. Dalam perspektif hukum pidana Islam, memperdagangkan pengaruh dapat digolongkan dalam kategori khiyanah atau ghulul (pengkhianatan) dan risywah (suap), sementara hukumannya diserahkan pada kebijakan hakim atau penguasa $\left(t a^{\prime} z i r\right)$.

\section{DAFTAR PUSTAKA}

\section{Buku dan Jurnal}

Alatas, Syed Hussein, Sosiologi Korupsi Sebuah Penjelajahan dengan Data Kontemporer, Jakarta: LP3ES, 1975.

Al-Bukhari, Al-Imam AbiAbdillah Muhammad Ibnu Ismail Ibnu Ibrahim Ibnu Mughirah Ibnu Bardazabah Al-Ja'fiyyi, Shahih Bukhari, Juz 3, Beirut-Libanon: Darrul kutub Ilmiyah, 1992.

Al-Qardawi, Muhammad Yusuf, al-Halal wa al-Haram fi al-Islam. Beirut: alMaktab al- Islami, 1994.

Al-Sijistani, Sulaiman ibn al-Asy'asy (Abu Dawud), Sunan Abi Dawud, Juz ke-9.

Al-Syaukani, Nail al-Autar, Juz. VIII (Kairo: Dar al-Hadith, t. th.).

Al-Tamimi, Abu Hatim Muhammad Ibn Hibban Ibn Ahmad, Sahih Ibn Hibban Beirut: Muassasah al-Risalah, 1414 H/1993 M.

Amundsen, Inge, Political Corruption: An Introduction to the Issues, Chr Michelsen Institute, Development Studies and Human Rights, Norwey, 1997.

An-Nawawi, Abi Zakariya Yahya bin Syarf, Riyadlu al-Shalihin. Surabaya: Nurul Huda, t.t. 
Baidlawi, Ahmad, "Pemberantasan Korupsi dalam Persepektif Islam", dalam Jurnal Esensia, Vol. 10, No. 2, Juli, 2009.

Faris, dkk., Donald, Kajian Implementasi Aturan Trading in Influence dalam Hukum Nasional, ICW, Maret 2014.

Hamzah, Andi, Pemberantasan Korupsi melalui Hukum Pidana Nasional dan Internasional. Jakarta: Raja Grafindo Persada, 2007.

Hollan, Miklos, Trading in Influence: Requirements of the Council of Europe Convention and the Hungarian Criminal Law, Acta Juridica Hungarica, Vol. 52, No 3, (2011).

Katsir, Ibn, Tafsir Al-Qur'an al-Adzim, Juz 1, Beirut: Dar al-Fikr, 1991.

Manohara, Brigita P., "Dagang Pengarung Trading in Influence di Indonesia". Jakarta: Raja Grafindo Persada, 2017.

Pope, Jeremy, Strategi Memberantas Korupsi: Elemen Sistem Integritas Nasional, Jakarta: Yayasan Obor Indonesia, 2003.

Prasetio, Muhammad Bondan Ferry, Kebijakan Kriminalisasi Memperdagangkan Pengaruh (Trading in Influence) sebagai Delik Korupsi di Indonesia, Diponegoro Law Journal, Volume 6, Nomor 1, Tahun 2017.

Saputra dan Ahmad Mahyani, Alvin, Tinjauan Yuridis Trading In Influence Dalam Tindak Pidana Korupsi, Mimbar Keadilan Jurnal Ilmu Hukum, Februari 2017.

Silvya E., Maria, Penegakan Hukum Korupsi Politik Law Enforcement on Political Corruption, Kanun Jurnal Ilmu Hukum, Vol. 21, No. 1, April 2019.

Tim Penulis Muhammadiyah dan Nahdlatul Ulama, Koruptor Itu Kafir. Jakarta: Mizan Publika, 2010.

\section{Internet}

Oxford Dictionaries. http:/ / www.oxforddictionaries.com

United States Institute of Peace (USIP), http ://www.usip.org/ apachesolrsearch/ trading\%20in\%20 influence 
Mohammad Farid Fad

Halaman ini sengaja dikosongkan 